\title{
Teenagers' Sexuality in Estonia and Finland in the 1990s
}

\author{
KRISTA PAPP \\ Researcher \\ Department of Public Health \\ University of Helsinki \\ Helsinki, Finland
}

\section{OSMO KONTULA}

\author{
Associate Professor \\ Department of Public Health \\ University of Helsinki \\ Helsinki, Finland
}

\section{ELISE KOSUNEN}

\author{
Acting Associate Professor \\ Department of General Practice \\ Medical School \\ University of Tampere \\ Tampere, Finland
}

\begin{abstract}
The present study assessed adolescent knowledge of sexual issues and sexual behavior in Estonia and Finland. The Estonian survey was conducted among students in the final grade of comprehensive school in March 1994, with a questionnaire translated from the Finnish KISS-92 study. The Estonian sample comprised 532 boys and 548 girls 15.0 years old on average; part of the Finnish KISS group of 1992, covering 680 boys and 687 girls 15.8 years old on average, served for comparison. Significance of difference was tested. Estonian adolescents were found to have significantly less sexual experiences than their Finnish counterparts. At the same time quite a large proportion of the Estonian adolescents were attitudinally ready to start sexual intercourse. From this point of view, it is alarming that knowledge of sexual issues was poor among Estonian adolescents: only one out of ten respondents had good and about one- half had poor knowledge of sexual issues. A good level of knowledge was five times more common among Finnish boys compared to Estonian boys. Among girls the difference was eightfold, respectively.
\end{abstract}

Keywords: adolescents, sexual knowledge, sexual behavior, Estonia, Finland

\section{Introduction}

Estonia and Finland had broad similarities in historical development and culture up to the 1940 s, when Estonia was incorporated into the Soviet Union. The new socialist ideology stressed the social roles and functions citizens should fulfill. First of all, dedicating one's energy to 
socially useful work was considered more important than a private life or an individual's sex life. Attitudes toward sexuality began to change in the 1970 s stressing the role of sexuality in marriage (Veispak 1989.) Moral values prevailing in socialist society were considerably in conflict with people's actual behavior. Similarly as in the West, the younger generation's acceleration became apparent: earlier attainment of maturity, awakening of erotic feelings, decrease in age of first sexual experience, and increased premarital sexual activity (Kon 1995).

With the liberalization of the society in the 1980 s sexual issues were increasingly dealt with in the media, although a lot of topics were still taboo. Adolescents' intercourse experiences were mostly dealt with as a problem of a small group of disturbed youngsters. A strict borderline between erotic and pornographic materials was not drawn, but the spreading of pornographic materials was punishable by law. In the early 1990 s restrictions on spreading materials on sexual issues were removed, and in a very short time materials which were earlier prohibited became available for everybody. These processes were quite similar to those in Finland at the end of the $1960 \mathrm{~s}$, at the time of "the sexual revolution".

Sex education first appeared in Estonian schools in 1963 when 10 lessons of personal hygiene were introduced into the general education curricula of the schools. The program prescribed 10 lessons during comprehensive school, taught separately to boys and girls. A survey conducted in 1970/71 among the students of the 8 th grade, the last grade of the comprehensive schools in Tallinn and in Tartu county, revealed that in the majority of schools at most only some parts of the program were implemented (Kurm 1979). Family-life education was introduced into Estonian secondary schools as an optional subject with 60 lessons in 1980/1981. The subject became compulsory for the 10th and 11 th grades starting from the school year of 1984/85, with a total of 35 lessons (Kurm 1990a).

At this point several new programs for sex education in comprehensive and secondary schools had been drawn up. The programs for comprehensive school contained information about sexual maturation, relationships with the opposite sex, and sexually transmitted diseases. The earliest programs disapproved of premarital sexual experiences whereas the latest programs accepted sexual intercourse when partners are in love and intend to marry each other. Adolescents' experiences of sexual intercourse were dealt with as a risk for depravity, sexually transmitted diseases, and unplanned pregnancies.

The comparison of Estonian and Finnish findings is of particular interest because in Estonia, for every thousand women 15-19 years of age in 1992, 49.9 gave birth to a child (Statistical Office of Estonia 1993) and another 55.5 had their pregnancies terminated (Eesti Meditsiinistatistika Büroo 1993). In Finland at the same time, the respective figures were 11.2 and 9.7 (The Nordic Council of Ministers 1996).

Twenty years ago, in the middle of the 1970s, these pregnancy and abortion figures in Finland were only a half of what they have been in Estonia in the 1990s. The differences between Estonian and Finnish societies have been enormous regarding the control of fertility. In Finland, after a new liberal abortion law was passed in the 1970s, emphasis was placed on decreasing the abortion rate and spreading information on contraception. In the former Soviet Union a liberal abortion law was passed in 1955 , but high abortion rates and the need for more effective contraception were not publicly discussed until the beginning of the 1990 s. At this same time the importance of sex education and counseling of adolescents on sexual issues was recognized. These first efforts were reflected in the abortion rates, for between 1992 and 1995 the abortion rate in the age group $15-19$ decreased from 55.5 to 40.9 per 1,000 women in Estonia (Karro, Klimas, and Lazdane 1997).

\section{Previous research}

In spite of efforts to provide sex education, a survey conducted among the graduates of the city and district of Tartu in 1988 revealed the poor quality of the sex education given in the schools and the inadequacy of the students' knowledge of sexual issues (Kurm 1990a, b). A survey conducted among 7th and 9th grade students of comprehensive schools in 1993 also 
revealed that quite a large proportion of the respondents had not obtained information on sexual issues at school and that the knowledge adolescents have about sexual matters was poor (Suurorg et al. 1995).

At the same time a survey conducted among 125 teachers in 1989/1990 showed that nearly all of the respondents $(98 \%)$ believed that it was important to discuss sexual matters at school. (Pilv 1991). The cooperation between medical workers and various other specialists in the field of sex education in general and the dissemination of contraception information in particular has got considerable attention since 1994 when the Family Planning Association of Estonia was founded (Karro 1995; Family Planning Association of Estonia 1996).

In Estonia sexual behavior studies on adolescents did not become possible until the end of the 1980s. Sexual behavior was included in a survey conducted among undergraduates of Tartu University and the Estonian Agricultural Academy in 1990. The results of the survey did not show age at the time of first sexual intercourse. According to the responses, $81 \%$ of the males and $87 \%$ of the females had not masturbated. One-fifth of the females and half of the males believed that masturbation was always right, and more than half of the female respondents said that masturbation was wrong in general/always wrong (Kutsar and Kontula 1993).

The 1993 study "School students' knowledge and attitudes concerning AIDS" included items concerning sexual experience. According to the results of the study, 53\% of the participating 9th grade (14-15-year-old) boys had experienced kissing, $41 \%$ had experienced caressing over clothing, $28 \%$ experienced caressing under clothing, $17 \%$ had had sexual intercourse, and $12 \%$ had masturbated. Of the participating 9 th grade girls, $54 \%$ had kissed, $34 \%$ had experienced caressing over clothing, and $19 \%$ experienced caressing under clothing, $10 \%$ had had sexual intercourse, and 4\% had masturbated (Suurorg et al. 1995).

In Finland, the first representative study of the sexual behavior of 18- to 54-year-old adults was carried out in 1971. This study was repeated in 1992 under conditions as similar as possible. The results showed that great changes had taken place in the sphere of sexual behavior during those decades. The first kissing and dating experiences started earlier and earlier until the beginning of the 1970s; after that no significant changes occurred. This is true also for first sexual intercourse (Sievers et al. 1974; Kontula and Haavio-Mannila 1993).

More detailed research into the sexual behavior of adolescents was initiated in the 1980s. Here the approach to the sexual behavior of adolescents was that they undergo a maturation process in which the experience of first kisses, caresses, and dating leads to sexual intercourse experience (Kontula and Meriläinen 1988; Kosunen 1993). According to these studies, the first dating experience coincides with sexual maturation. A comparison of the sexual experience of 13-, 15- and 17-year-old respondents revealed, at all levels of sexual experience studied, that a significant increase in sexual experience occurred together with increasing age. The rate of first sexual intercourse experienced increases particularly sharply between 16 and 17 years of age (Kontula 1987; Kontula and Meriläinen 1988; Kannas 1993). According to the latest studies, around $30 \%$ of 9 th grade girls, aged between 15 and 16 , and $19-25 \%$ of the same-aged boys have experienced sexual intercourse (Kannas 1993; Kosunen 1993).

In the surveys conducted in schools (Kontula 1991; Lehtonen 1996), two-thirds of the adolescents have reported receiving some sex education already before the age of 13 . At the age of 13 (grade 7), sex education had been received by one-third during the year of the survey; at the age of 15 (grade 9), by four-fifths.

According to the results of a survey carried out among biology teachers in 1996, sex education was mainly obtained in the 9 th grade (Kontula 1997). The teachers were motivated to give sex education. This may be explained by overall tolerant attitudes in society towards sexual experiences in the dating relationships of adolescents.

The aim of this study was to compare knowledge on sexual issues and sexual behavior among adolescents in Estonia and Finland. Our hypothesis was that the Estonian students' knowledge of sexual issues was somewhat weaker than that of Finnish counterparts. This may be a cause of the high rates of unplanned pregnancies. Because of intolerant attitudes towards adolescent sexuality in Estonian society we expected Estonian adolescents to have less sexual experience than Finns. 


\section{Materials and methods}

The basis of this study was the KISS study (acronym from the Finnish words meaning maturation, human relationships, dating, and sexual behavior of pupils) carried out in Finland in 1986,1988 and 1992. The Finnish study was used as the basis due to very limited survey experience available in Estonia, particularly in the sphere of sexual matters. The Estonian survey was conducted among students in the final grade of comprehensive school in March 1994, with a questionnaire translated from the Finnish KISS -92 study. The questionnaire contained questions about the adolescents' social life, knowledge on sexual issues, moral beliefs, and actual sexual experiences. Five Estonian towns and cities including their surrounding counties were chosen for the study: Tallinn (the capital), Tartu (the university city with a large number of people with a completed higher education degree, representing the mid-south part of Estonia), Pärnu (a holiday resort, representing the western part of Estonia), Jôgeva (the only county where the size of the rural population exceeds the urban one, representing the mid-east part of Estonia), and Viljandi (representing central Estonia). Different kinds of schools from each area were chosen to be included in the study. City schools were represented both by regular comprehensive schools and by high-status, partially foreign-language-immersed schools which select their students on the basis of entrance tests. Among rural schools, those further away from bigger towns and cities were chosen. There was only one partially foreign-language-immersed school in each town, but comprehensive and rural schools were chosen at random (see Papp 1997).

The Estonian sample consisted of 532 boys and 548 girls. About $9 \%$ of the 9 th grade students of all Estonian comprehensive schools in which the language was Estonian participated in the study. In order to compare the sexual behavior and knowledge of sexual issues of Estonian and Finnish adolescents, results from the KISS study carried out in Finland in the spring of 1992 were used. In the Finnish sample the responses of 9 th grade students, covering 680 boys and 687 girls, served as the comparison group. In Finland, the areas participating in the study had been chosen on the basis of earlier studies, according to which Helsinki and Pohjanmaa (western Finland) showed the greatest divergence in moral beliefs. Further, there was a difference between the rural and the urban districts. Orimattila and Mäntsälä representing the countryside of southern Finland and Valkeakoski representing small towns were included in the study in order to make the study results more inclusive (Kontula and Meriläinen, 1988). The Finnish sample does not represent the whole country, but gives a survey of different areas of the country.

In the Estonian sample the capital area is not represented as well as in the Finnish sample.

Table 1. Distribution of the Estonian and Finnish respondents by residence (\%).

Residence

Capital

Towns

Rural areas

Total

$(\mathrm{N})$
Estonian \%

17

48

35

100

1,080
Finnish \%

$$
\begin{array}{r}
32 \\
42 \\
26 \\
100 \\
1,367
\end{array}
$$

In the Finnish study the subjects are somewhat older than in the Estonian study. In the calculation of mean age the exact age of the respondent in years and months at the moment of the study were taken as the baseline values. Estonian boys wère on average 15.1 and Finnish boys 15.8 years old; Estonian girls were on average 15.0 and Finnish girls 15.8 years old. This age difference is due to the fact that the Estonian subjects began school at the age of six, i.e. one year earlier than the Finnish children.

In processing the data concerning sexual experiences, the age at having one's first sexual experience of all kinds of sexual experiences was given as a cumulative percentage up to the age of 15 . This way it was possible to avoid any influence which might come from the answers 
of the older students. A comparison of sexual experience is based on the 15-year-old respondents of each sample. Thus, responses of 251 boys and 235 girls from Estonia and 321 boys and 324 girls from Finland were analyzed. Knowledge of sexual issues was analyzed from all samples, because the aim of this study was to investigate knowledge and sources of information on sexual matters in the final grade of comprehensive school.

The questionnaire contained 20 knowledge items concerning maturation, conception, contraception, sexually transmitted diseases, and other matters relating to human sexuality and sexual behavior. On the basis of these, a summed index was compiled in which a correct answer received 1 point and an incorrect or missing response received 0 points. The results were divided into levels of knowledge: good knowledge 15-20 points; average knowledge 10-14 points; poor knowledge 9 or less points.

Non-parametric values were compared using Pearson's chi-square-test. Correlation analyses were calculated using Spearman's bivariate correlation.

\section{Results}

\section{Knowledge of sexual issues}

In order to compare the knowledge of Estonian and Finnish respondents regarding sexual maturity and conception, the correct responses to the corresponding items (Table 2) were analyzed separately. On each item, the proportion of the Finnish respondents who knew the correct answer was significantly greater than that of the Estonian respondents. The poor knowledge of the Estonian boys was most significant in their responses to the following questions: is the onset of menses a sign of a girl's sexual maturation, can a girl become pregnant during her very first intercourse, can a drop of sperm on a woman's genitalia cause pregnancy, and what is the most likely phase for conception during a menstrual cycle. A significant, but less marked difference between the knowledge of the boys of the two countries was observed in their responses to the question of whether the onset of ejaculation is a sign of sexual maturity.

Table 2. Proportion of correct responses to questions concerning sexual maturity and conception among Estonian and Finnish respondents by gender $(\%)$.

\begin{tabular}{|c|c|c|}
\hline Item & Estonian boys & Estonian girls \\
\hline & $\% \quad(\mathrm{~N})$ & $\% \quad(\mathrm{~N})$ \\
\hline $\begin{array}{l}\text { Menarche is } \\
\text { a sign of sexual } \\
\text { maturity }\end{array}$ & $\begin{array}{l}40 \quad(515) \\
\chi^{2}=149.5, \text { d. f. }=2, p \leq 0.001\end{array}$ & $\begin{array}{l}53 \quad(547) \quad 88 \quad(684) \\
\chi^{2}=189.5, \text { d. f. }=2, p \leq 0.001\end{array}$ \\
\hline $\begin{array}{l}\text { The most likely } \\
\text { phase of the menstrual } \\
\text { cycle for conception }\end{array}$ & $\begin{array}{l}11 \quad(500) \\
\chi^{2}=49.5, \text { d. f. }=2, p \leq 0.001\end{array}$ & $\begin{array}{l}17 \quad(534) \quad 59 \\
\chi^{2}=219,7, \text { d. f. }=2, p \leq 0.001\end{array}$ \\
\hline $\begin{array}{l}\text { Onset of } \\
\text { ejaculation is a sign } \\
\text { of sexual maturity }\end{array}$ & $\begin{array}{l}80(521) \\
\chi^{2}=39.2, \text { d. f. }=2, p \leq 0.001\end{array}$ & $\begin{array}{l}74 \quad(541)=91 \\
\chi^{2}=75.8, \text { d. f. }=2, p \leq 0.001\end{array}$ \\
\hline $\begin{array}{l}\text { Becoming pregnant is } \\
\text { possible during one's } \\
\text { first sexual intercourse }\end{array}$ & $\begin{array}{l}62 \quad(518) \quad 81 \quad(676) \\
\chi^{2}=174.1, \text { d. f. }=2, p \leq 0.001\end{array}$ & $\begin{array}{l}64 \quad(544) \quad 85 \\
\chi^{2}=203.4, \text { d. f. }=2, p \leq 0.001\end{array}$ \\
\hline $\begin{array}{l}\text { A drop of sperm } \\
\text { on a woman's genitalia }\end{array}$ & $\begin{array}{l}62 \quad(518) \\
\chi^{2}=159.6, \text { d. f. }=2, p \leq 0001\end{array}$ & $\begin{array}{l}51 \quad(542) \quad 91 \\
\chi^{2}=215.9, \text { d. f. }=2, p \leq 0.001\end{array}$ \\
\hline
\end{tabular}

In comparing the knowledge of the girls, it is obvious that more Estonian than Finnish girls were poorly informed about the connection between the onset of menstruation and sexual matu- 
ration, the possibility of becoming pregnant during the first sexual intercourse, the possibility of pregnancy being caused by a drop of sperm on a woman's genitalia, and the phase of the menstrual cycle when the likelihood of conception is the highest. The difference was somewhat less marked in responses to the question of whether the onset of ejaculation is a sign of a boy's sexual maturity; here also the knowledge levels of the Estonian girls were poorer.

In comparing the knowledge levels of respondents in the two countries, it should be kept in mind that the Estonian 9th grade students were younger than their Finnish 9th grade counterparts. To assess the impact of age, the knowledge of the 14- and 15-year-old Estonians, and of 15- and 16-year-old Finns was compared. It appeared that among the Estonians an increase in knowledge had no significant correlation with an increase in age $\left(r_{s}=-0.02, n\right.$. s. $)$. Among the Finnish youth, however, good knowledge had a positive correlation with an increase in age $\left(\mathrm{r}_{\mathrm{s}}=\right.$ $0.06, p \leq 0.05)$, i.e. the older students were generally slightly better informed about sexual matters than their younger counterparts.

Table 3. Distribution of Estonian and Finnish respondents based on level of knowledge by gender (\%).

$\begin{array}{lrrrr}\begin{array}{l}\text { The level of } \\ \text { knowledge }\end{array} & \text { Estonian boys \% } & \text { Finnish boys \% } & \text { Estonian girls \% } & \text { Finnish girls \% } \\ \text { Good } & 9 & 48 & 8 & 69 \\ \text { Average } & 51 & 45 & 39 & 27 \\ \text { Poor } & 40 & 7 & 53 & 4 \\ & & & & \\ \text { Total } & 100 & 100 & 100 & 100 \\ \text { (N) } & (529) & (680) & (547) & (687)\end{array}$

The difference in sexual knowledge (Table 3) between the Estonian and Finnish boys was statistically significant $\left(\chi^{2}=296.4\right.$, d. f. $\left.=2, p \leq 0.001\right)$ : the level of knowledge was clearly higher among the Finnish boys. The same was true for the girls: the level of knowledge was significantly better among Finnish girls $\left(\chi^{2}=577.7\right.$, d. f. $\left.=2, p \leq 0.001\right)$. The Finnish respondents had significantly better knowledge of sexual maturity and impregnation, sexually transmitted diseases, and other issues related to human sexuality and sexual behavior. In knowledge about contraception the difference was less significant.

Considerably more sex education instruction had been offered the Finnish adolescents compared to the Estonian: in the year of the interview $95 \%$ of the Finns and $60 \%$ of the Estonians took part in school sex education classes. About three-fourths of the Finnish respondents and one-fourth of the Estonian students stated that sex education was given in several classes. Most of the Finnish respondents said that the discussion of most of the topics included in study was thorough, while Estonian students reported that these topics were merely mentioned in their sex education classes. Estonian respondents also talked about sexual matters at home and with their friends significantly less than Finnish counterparts.

\section{Sexual experience}

It appeared that among Estonian boys (Figure 1) the first kissing experiences started before the age of ten. The first experiences caressing over clothing (light petting) started from the age of eleven, and experiences of heavy petting (caressing under clothing or in the nude) and masturbation at the age of 12 . In respect to sexual intercourse, the first experiences started at the age of 13 , but the increase of such experiences was not so remarkable as in the case of kissing and petting experiences. It is obvious that Finnish boys had more experience than Estonian boys of the same age with all varieties of sexual experiences included in the study. The only exception was sexual intercourse, where Estonian boys had somewhat more experience before the age of 14.

Among the female respondents, it can be observed that (Figure 2) for Estonian girls the first 
Figure 1. Sexual experiences of Estonian and Finnish male respondents (cumulative \%).

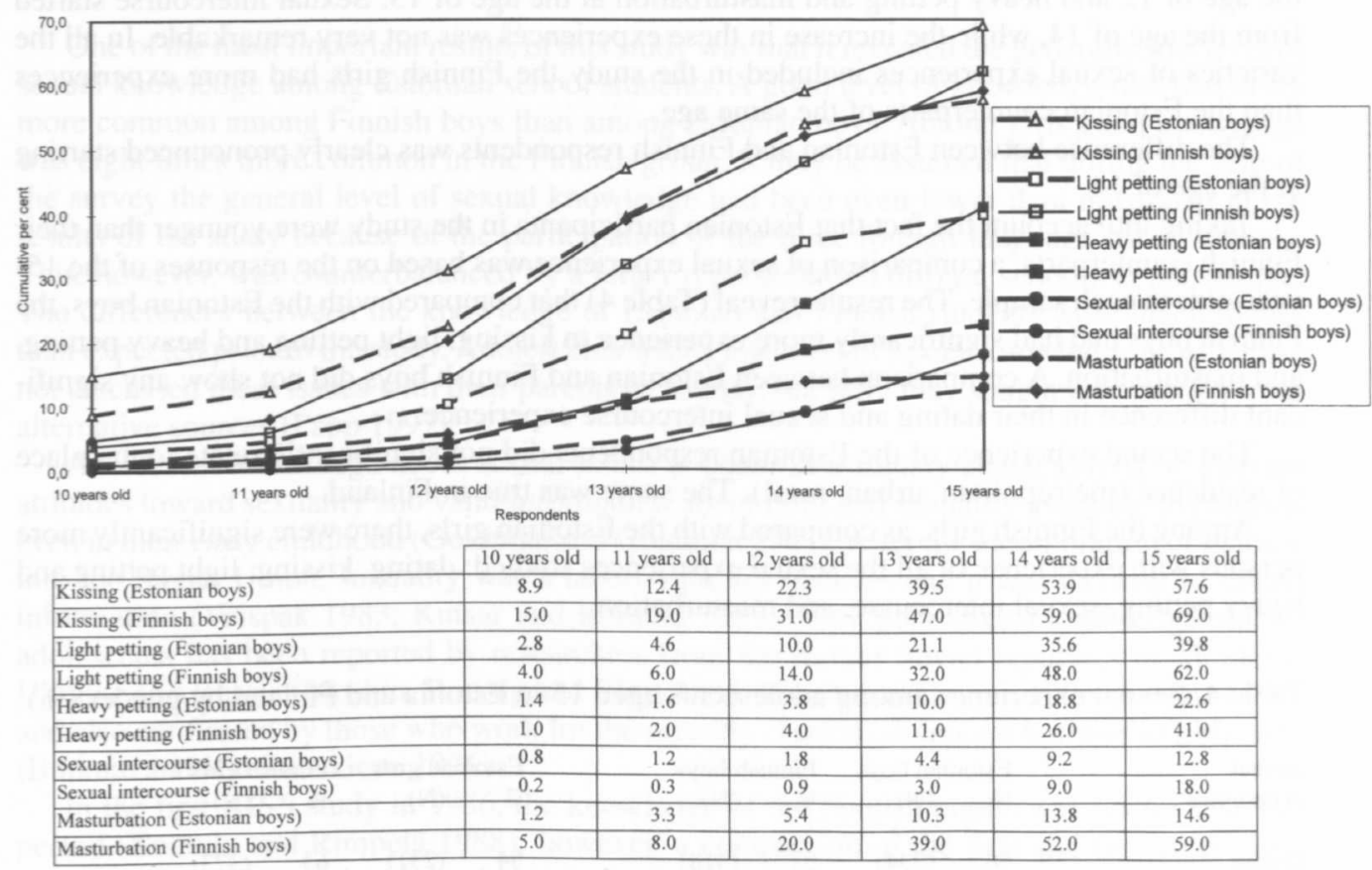

Figure 2. Sexual experiences of Estonian and Finnish fermale respondents (cumulative \%).

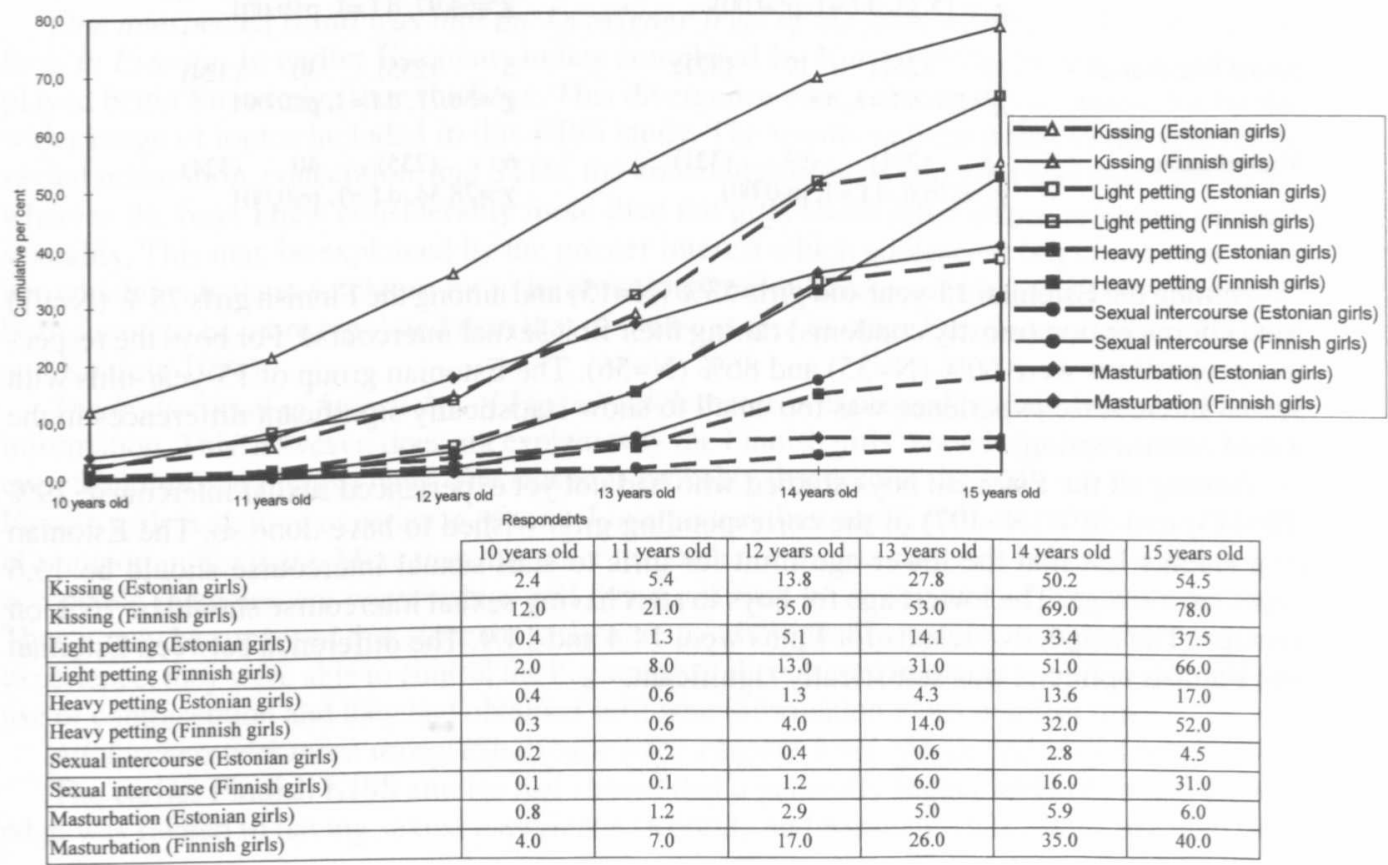


experiences of kissing started before the age of 12 . The experiences of light petting started from the age of 12 and heavy petting and masturbation at the age of 13. Sexual intercourse started from the age of 14 , while the increase in these experiences was not very remarkable. In all the varieties of sexual experiences included in the study the Finnish girls had more experiences than the Estonian counterparts of the same age.

The difference between Estonian and Finnish respondents was clearly pronounced starting at the age of 14 .

Taking into account the fact that Estonian participants in the study were younger than their Finnish counterparts, a comparison of sexual experience was based on the responses of the 15year-olds in each sample. The results reveal (Table 4) that compared with the Estonian boys, the Finnish boys had had significantly more experience in kissing, light petting and heavy petting, and masturbation. A comparison between Estonian and Finnish boys did not show any significant difference in their dating and sexual intercourse experience.

The sexual experience of the Estonian respondents did not significantly relate to the place of residence (metropolitan, urban, rural). The same was true in Finland.

Among the Finnish girls, as compared with the Estonian girls, there were significantly more persons with experience of all the sexual experiences studied: dating, kissing, light petting and heavy petting, sexual intercourse, and masturbation.

Table 4. Sexual experience among adolescents aged 15 in Estonia and Finland by gender (\%).

\begin{tabular}{|c|c|c|}
\hline Sexual & Estonian boys & Estonian girls Finnish girls \\
\hline experience & $\% \quad(\mathrm{~N})$ & $\% \quad(\mathrm{~N})$ \\
\hline Dating & $\begin{array}{l}56 \quad(234) \\
\chi^{2}=0.44 \text {, d.f. }=1, \text { n.s. }\end{array}$ & $\begin{array}{l}54 \quad(231) \\
\chi^{2}=4.68, \text { d.f. }=1, p \leq 0.05\end{array}$ \\
\hline Kissing & $\begin{array}{l}54 \quad 69 \\
\chi^{2}=14.19, \text { d.f. }=1, p \leq 0.001\end{array}$ & $\begin{array}{l}54 \quad(235) \quad 78 \\
\chi^{2}=40.24, \text { d.f }=1, p \leq 0.001\end{array}$ \\
\hline Light petting & $\begin{array}{l}38 \\
\chi^{2}=29.55, \text { d.f. }=1, p \leq 0.001\end{array}$ & $\begin{array}{l}38 \quad \begin{array}{l}(235) \\
\chi^{2}=46.26\end{array}, \text { d.f. }=1, p \leq 0.001\end{array}$ \\
\hline Heavy petting & $\begin{array}{l}23(251) \\
\chi^{2}=15.33, \text { d.f. }=1, p \leq 0.001\end{array}$ & $\begin{array}{l}19(235) \quad 52 \\
\chi^{2}=64.97, \text { d.f. }=1, \mathrm{p} \leq 0.001\end{array}$ \\
\hline Sexual intercourse & $\begin{array}{l}13 \quad(251) \\
\chi^{2}=1.4, \text { d.f. }=1, \text { n.s. }\end{array}$ & $\begin{array}{l}5 \quad(235) \quad 30 \\
\chi^{2}=56.72, \text { d.f }=1, p \leq 0.001\end{array}$ \\
\hline Masturbation & $\begin{array}{l}15 \\
\chi^{2}=276.6, \text { d.f. }=1, p \leq 0.001\end{array}$ & $\begin{array}{l}6 \quad(235) \quad 40 \\
\chi^{2}=78.34, \text { d.f. }=1, p \leq 0.001\end{array}$ \\
\hline
\end{tabular}

Among the Estonian 15-year-old girls 53\% (N=15) and among the Finnish girls 75\% (N=97) used contraception (mostly condoms) during their first sexual intercourse. For boys the respective proportions were $60 \%(\mathrm{~N}=35)$ and $86 \%(\mathrm{~N}=56)$. The Estonian group of 15 -year-olds with sexual intercourse experience was too small to show statistically significant differences in the use of contraception.

Among all the Estonian boys studied who had not yet experienced sexual intercourse $79 \%$ $(\mathrm{N}=443)$ and $38 \%(\mathrm{~N}=497)$ of the corresponding girls wished to have done so. The Estonian respondents felt that the lower age limit for girls to start sexual intercourse should be 15.6 years, on average. The lowest age for boys to start having sexual intercourse should be 16.2 , on average. The respective results for Finns were 14.4 and 14.9. The difference between Estonian and Finnish opinions was statistically significant. 


\section{Summary and discussion}

One of the most important results of this study was that it revealed the generally low level of sexual knowledge among Estonian school students. A good level of knowledge was five times more common among Finnish boys than among Estonian boys. Among girls good knowledge was eight times more common in the Finnish group. It may be assumed that during the year of the survey the general level of sexual knowledge had been even lower than illustrated in the results of the study because of the participation of the three foreign-language-based schools. This, however, was counterbalanced by a larger representation of rural schools in the sample. The differences between the knowledge of Estonian and Finnish students were much higher than expected prior to the study. Adolescents with a low level of sexual knowledge mostly have not discussed these issues with their parents or friends, nor have they sought information from alternative sources (Papp 1997).

Adolescent knowledge about sexual issues is better in a society characterized by tolerant attitudes toward sexuality and valid information about birth and sexuality available to children even in their early childhood (Goldman and Goldman 1983). After the incorporation of Estonia into the Soviet Union, sexuality was a taboo topic for decades and it was difficult to obtain information (Veispak 1983; Kutsar and Kontula 1993). Very poor sexual knowledge among adolescents has been reported by researchers from the former Soviet republics of Moldova, Ukraine and Russia (Moshin, Bodrug and Blaja 1996; Vornik and Govrun 1996; Alesina 1996) and also confirmed by those who work for the recently created adolescent hotlines in Lithuania (Butkute and Kabasinskiene 1996).

In the first KISS study in 1986, the knowledge of the Finnish pupils was poorer than expected (Kontula and Rimpelä 1988); however, a comparison of the first and the latest study results showed the level of knowledge to have risen significantly (Kosunen 1993 a). This is obviously true because of more efficient sex education. In Estonia sex education has been poor.

The level of knowledge about sexual maturation and conception in this study revealed that Estonian adolescents did not have sufficient and understandable information available about processes happening in their own bodies. The fact that adolescents know very little about the processes taking place in a woman's body during her menstrual cycle or during pregnancy has also been demonstrated in earlier Estonian studies. Girls are well informed only about requirements for hygiene during menstruation (Kurm 1979, 1990 a).

One unexpected result was that the knowledge level of the girls was lower than that of the boys in Estonia. In earlier Estonian studies completed by Kurm (1979, 1990a), the girls displayed better knowledge than the boys. This divergence can probably be accounted for by the wider range of topics included in this KISS study. The results indicated that in the spheres of sexual maturation, conception, and STDs, the knowledge of boys and girls was much the same, whereas the boys knew considerably more than the girls about other issues related to human sexuality. This may be explained by the greater interest which adolescent boys have in sexuality, which leads them to obtain more information from different sources. Girls' sexuality has been found to be more regulated than that of the boys also in other European countries (Bozon and Kontula 1998).

The higher level of knowledge of Finnish adolescents is explained by their better sources of information. This, however, does not explain why the Finnish girls' knowledge levels were better even than those of Finnish boys. The reason is probably that among the adolescents studied, the Finnish girls had more experience of sexual intercourse than any Estonians. Sexual issues were also important for them. More than any other respondents, the Finnish girls believed that sex was acceptable in adolescent relationships and that a girl may be an initiator of sexual intercourse. Thus it may be supposed that since the girls were psychologically mature enough to have sexual experience, they were able to control the beginning of their sexual intercourse experience and the use of contraception and they had obtained sufficient information to accomplish this.

Adolescents with more sexual experience have a higher level of knowledge on sexual issues.

The earlier Finnish KISS studies had shown that a generally higher level of sexual knowledge was related to having sexual experience (Kontula and Rimpelä 1988). This has also been 
confirmed by the Estonian results (Papp 1997). It is hard to judge on the basis of the results whether good knowledge precedes experience, or whether young people make use of different information sources after they have acquired experience. Based on the dates of surveys carried out in the Western countries, the latter supposition is more probable.

Acquiring sexual experience is a process starting with kissing, dating, and light petting, which is confirmed by earlier results of the Finnish KISS research (Kontula and Meriläinen 1988). Estonian society accepted adolescents' romantic feelings towards the opposite sex but disapproved of sexuality in the relationships of adolescents. Thus we did not find great differences in sexual initiation. The main difference was that during courtship Estonian adolescents had significantly less sexual intimacy than Finns.

Estonia was a traditional society with a double standard: men gained different sexual rights than women. Estonian boys had more experience of heavy petting, sexual intercourse, and masturbation than girls of the same age. Thus it is obvious that boys were less restricted by norms established by society and they tended to be the initiators in sexual relationships. The results are similar to those obtained from "School students' knowledge and attitudes concerning AIDS“ in 1993 (Suurorg et al. 1995).

According to the results of this study, the level of sexual experience does not depend on region (rural, urban, metropolitan). Earlier Finnish studies (Kontula 1991), have found that young people who live in rural districts have fewer sexual experiences than those who live in the capital area. That can be explained by stronger social control and more conservative attitudes among adults in the country. Such differences in adolescents' sexual behavior have decreased and the last KISS study found only small differences between different regions. It implies a homogeneity in the teenage culture (Kosunen 1993).

The results in Estonia can be interpreted in terms of the long-term policy of integrating urban and rural districts, in which urban-type houses were built in the countryside, where people usually worked on collective farms. Under such circumstances, the mechanisms of social control did not function in the way they did for people living on farmsteads.

The development of gender equality in Estonia leads to increased sexual activity among girls. It might be supposed that when girls actively seek sexual experiences, they feel more responsibility for contraception. These trends were also found among Finnish adolescents.

The small number of adolescents admitting to masturbation raises a question about the reliability of this study, but studies on Estonians' knowledge about AIDS in 1993 yielded similar results (Suurorg et al. 1995). Most of the Estonian university students surveyed by Kutsar (Kutsar and Kontula 1993) regarded autoerotic pleasure as improper, and a small number of those surveyed had had this experience. Articles published earlier as well as the program of sex education for schools published in 1986 (Eesti NSV Haridusministeerium) considered masturbation among adolescents as a vice and recommended weaning oneself away from it. Therefore, it may be supposed that young people in Estonia still do not approve of masturbation. Some are aware of the negative attitudes of society toward masturbation, and they dare not report their own practice. The impact of society on teenagers' sex culture was clearly revealed in the comparison of Estonian and Finnish adolescents who had experienced masturbation.

The proportion of adolescents having had sexual intercourse among those surveyed showed that the Estonian results were closer to those from studies in France and Switzerland than those in the Nordic countries (Bozon and Kontula 1998). Considering that four girls out of ten and three boys out of four reported a desire to have sexual intercourse, it can be supposed that the number of adolescents who have experienced sexual intercourse will be considerably higher among Estonian 16-year-olds.

Sex education at school and other sources of information on sexual issues must be improved in Estonia. Further studies are also needed. By conducting the KISS study in the same schools for a second time, as was done in Finland, it would be possible to estimate changes in adolescent knowledge and the role and effect of different information sources as well as to detect changes in adolescents' sexual behavior. Adolescents with experience of sexual intercourse and pregnant adolescents need to be studied separately: interviews and focus-group discussions with them would help reveal reasons for insufficient use of contraception, motives for starting sexual experiences and possibilities for better counseling for those youngsters. 


\section{References}

Alesina, I. 1996. Adolescent sexual health initiative in Russia. Choices: sexual health and family planning in Europe 25(2):16-17.

Bozon, M. and O. Kontula. 1998. Sexual initiation and gender in Europe: a cross-cultural analysis of trends in the 20th century. In: Sexual behavior and HIVIAIDS in Europe, edited by Michael Hubert et al. London: UCL Press.

Butkute, A. and R. Kabasinskiene. 1996. Lithuanian phone helpline reaching out to youth. Choices: sexual health and family planning in Europe 25(1):16-17.

Eesti Meditsiinistatistika Büroo. 1993. Aastaaruanne. Unpublished material.

ENSV Haridusministeerium. 1986. Uldhariduskooli programmid: Tervishoid. Perekonnaôpetus. Tallinn: Valgus,

Family Planning Association of Estonia. 1996. Annual report manuscript. Tallinn.

Flanigan B., A. McLean, C. Hall, and V. Propp. 1990. Alcohol use as a situational influence on young woman's pregnancy risk-taking behaviors. Adolescence 25:205-214.

Goldman, R. and J. Goldman. 1983. Children's perceptions of sex differences in babies and adolescents: a cross-national study. Archives of Sexual Behavior 12:277-294.

Kannas, L. 1993. Ihana tukala seksuaalisuus (Sweet troublesome sexuality). Sosiaali- ja Terveysministeriön ehkäisevän sosiaali- ja terveyspolitiikan osasto. Selvityksiä 1993, No. 4. Helsinki: Sosiaali- ja terveysministeriö.

Karro, H. 1995. Miks pereplaneerimine? Bülletään nr.1:5-8 Eesti Pereplaneerimise Liit,Tallinn.

Karro H, V. Klimas, and G. Lazdane. 1997. Reproductive health in the Baltic countries. Choices: sexual health and family planning 26(1):13-17.

Kon, I. 1995. The sexual revolution in Russia. In: From the age of the czars to today. New York: The Free Press.

Kontula, Osmo. 1987. Nuorten seksi. Helsinki: Otava.

Kontula, Osmo. 1991. Nuorten tiedontarve (Adolescents' need of sexual knowledge). In: Seksistä-kuinka puhua nuorille?, edited by Osmo Kontula, pp. 37-52. Helsinki: Otava.

Kontula, Osmo. 1997. Yläasteen sukupuolikasvatus lukuvuonna 1995-1996 (Sex education at the upper stage of the comprehensive school in the school year 1995-1996). Sosiaali- ja terveysministeriön selvityksiä 1997, No. 3. Helsinki: Sosiaali- ja terveysministeriö.

Kontula Osmo and Elina Haavio-Mannila. 1993. Suomalainen seksi: tietoa suomalaisten sukupuolielämän muutoksesta (Finnish sex: information on the change of the sex life of the Finns). Helsinki-PorvooJuva: WSOY.

Kontula, Osmo and Elina Haavio-Mannila. 1995. Sexual pleasures: enhancement of sex life in Finland, 1971-1992. Aldershot, Hampshire: Dartmouth.

Kontula O. and J. Meriläinen. 1988. Nuorten kypsyminen seurusteluun ja seksuaalisuuteen (Adolescent maturation to courtship and sexuality). Lääkintöhallituksen julkaisuja. Sarja Tutkimukset 1988 , No. 9. Helsinki.: The National Board of Health.

Kontula O. and M. Rimpelä. 1988. Nuorten tiedot sukupuolisesta kehityksestä (The knowledge of young people of sexual development). In: Terveyskasvatustutkimuksen vuosikirja 1988 , edited by L. Kannas and J. Miilunpalo, pp. 141-156. Lääkintöhallituksen julkaisuja. Terveyskasvatus. Sarja Tutkimukset 1988, No. 8. Helsinki: National Board of Health.

Kosunen, E. 1993. Teini-ikäisten raskaudet ja ehkäisy (Pregrancies and contraception of teenagers). Raportteja, No. 99. Helsinki: STAKES.

Kurm, H. 1979. Kaheksandate klasside ôpilaste teadmised seksuaalsest tervishoiust isikliku hügieeni kursuse pôhjal. Nôukogude Kool 11: 947-951.

Kurm, H. 1990a. Perekonnaôpetus koolis I. Haridus 1:25-27.

Kurm, H. 1990b. Perekonnaôpetus koolis II. Haridus 2:23-24.

Kutsar, D. and O. Kontula. 1993. Students' sexual attitudes and behavior: Finland and Estonia in comparison. Unpublished manuscript. Tartu.

Lehtonen, Mervi. 1996. Seksuaalikasvatus peruskoulun yläasteilla Keski-Suomessa, kevät 1996 (Sex education at the upper stages of the comprehensive school in Central Finland in the spring of 1996). Jyväskylä: Keski-Suomen Lääninhallitus.

Moshin V., V. Bodrug, and M. Blaja. 1996. Adolescent sexual health in Moldova. Choices: sexual health and family planning in Europe 25(2):22-23.

Papp, K. 1997. Knowledge on sexual issues, moral beliefs and sexual experience among adolescents in Estonia and Finland. Research reports, No. 82. Helsinki: STAKES.

Pilv I. 1991. Uus eesti kooli terviseöpetuse programm ja meditsiinitöötajate ülesanded selle ellurakendamisel. Eesti Arst 3:224-226.

Sievers K., O. Koskelainen, and K. Leppo. 1974. Suomalaisten sukupuolielämä (Finnish sex life). PorvooHelsinki:WSOY.

Statistical Office of Estonia. 1993. Statistical yearbook. Tallinn.

Suurorg L., P. Kaldmäe, V. Sirge, T. Valvas, L. Kannas, and J. Tynjälä. 1995. Kooliôpilaste seksuaalalased teadmised, seksuaalkäitumine, informeeritus HIV/AIDS-ist ning möningaid sotsialiseerumise aspekte. Eesti Arst 2:119-122. 
The Nordic Council of Ministers. 1996. Yearbook of Nordic Statistics 1977-1995. Vols. 16-33. Copenhagen. Veispak T. 1989. Seksuaalideoloogia Eesti ûhiskondlikus teadvuses 20. sajandil. Vikerkaar 6:60-70.

Vornik B. and T. Govorun. 1996. Challenges in the Ukraine. Choices: sexual health and family planning in Europe. 25(2):13-15. 